made (or sheep-made) that sheep have become an essential part of them, and even in reserves must be used, if, for instance, introduced grasses such as Yorkshire fog are to be kept under control. It is hoped that the agreed new management plan for southern New Island will be a first step towards reconciling sheep farming and wildlife conservation.

\title{
Arid Ecosystems
}

R. S. R. FITTER

The best reason for holding a workshop on the management of arid ecosystems in Cairo last November was that hardly anywhere in the world could any of the participants cite any instances of arid ecosystems being actually managed. Examples of the mistreatment are galore. Cairo itself stands in the middle of one of the largest arid ecosystems in the world, stretching from the coast of Morocco through Arabia to the Gobi Desert. The history of human civilisation, especially in its earlier millennia, is largely the history of the destruction of once fertile lands-part of the Middle East was once called the Fertile Crescent-and North Africa, now largely desert, was once the granary of Rome, the resource base of the world's first great international empire. The modern world shows little sign of heeding the lessons of the past. Despite the UN Desertification Conference in Nairobi last year, which produced many sound recommendations, the conservation of the remaining fertility of the world's arid regions still commands as little priority as any other enterprise that does not show an immediate profit on the balance sheet.

The Cairo Workshop, jointly sponsored by the Egyptian Academy of Scientific Research Technology and the US Department of the Interior, marked a first small step towards sanity. But the Sahara desert continues to advance southwards much faster than governments are taking effective action to check it. Sahel countries had good rains this year, so politicians at once think that after all it is not so urgent to do the inconvenient things they must do if the desert is not to spread. The Arabian oryx, now probably extinct, and the addax and scimitar-horned oryx, now well on the way to extinction, are the animals designed by nature to graze the arid lands, and were once numerous enough to be domesticated in ancient Egypt. Their successors brought by man, the cow, the sheep and the goat, have been the main instruments of the destruction of the fertility of those arid lands. Perhaps there is sc-nething in wildlife conservation after all?

\section{Natural Areas on World Heritage List}

The first 12 areas to be selected for the World Heritage list include four Natural Heritage Areas: Nahanni National Park, Canada; Galapagos Islands, Ecuador; Simien National Park, Ethiopia; and Yellowstone National Park, USA. Nahanni, a vast almost untouched wilderness of 1850 square miles in north-west Canada which includes the Mackenzie Mountains, covers habitats ranging from alpine tundra to subalpine and boreal forests and harbours Dall sheep, mountain goat, grizzly bear, grey wolf, caribou, peregrine falcon, golden and bald eagles and trumpeter swan; the Galapagos in the Pacific, with their extraordinary tally of endemic plants and animals, were an obvious choice; Simien, $165 \mathrm{sq} \mathrm{km}$ of spectacular mountain scenery on the north ledge of the Ethiopian plateau, harbours the rare walia ibex, Simien fox and gelada baboon; Yellowstone, $100,000 \mathrm{ha}$, with spectacular scenery, geysers, and the largest caldera on earth, harbours endangered and threatened species, including grizzly bear, mountain lion (cougar), Artic grayling, bald eagle and trumpeter swan as well as mule deer, elk, moose, bison, black bear, coyote and pronghorn. 